\title{
Akik majdnem megnyerték az Atlanti csatát - A Kriegsmarine U VII. osztályú tengeralattjárói m.resz
}

\section{ÖSSZEFOGLALÁs}

A második világháború német tengeralattjáró flottájának a gerincét a VII. osztály búvárhajói adták. Az 1121 db megépült U-boot közül 709 darab tartozott közéjük. Gyártásuk gyakorlatilag a világháború kezdetétől folyt. Harci technikai jellemzőik a háború során nem sokat változtak. A VII/B változattól kezdődően a hatótávolságuk sem növekedett. A háború elején, amikor még aránylag kevés és rossz felszereltségű kísérőhajó őrízte a konvojokat, a lemaradt, vagy kísérő nélküli kereskedelmi hajókat fedélzeti 88 mm-es lövegükkel sülyesztették el, hogy torpedókészletüket kíméljék. A háború első két évében a VII. osztály hajóival elsősorban éjjel és rossz időjárási körülmények között a vízfelszínen támadtak, majd a védelem erősödése után vízfelszínen követték a konvojokat, majd az éjszakát megvárva a konvojok oldalán lemerülve törték át a kísérőhajók vonalát, és legyezőirányban indították a torpedóikat. $\mathrm{Az}$ egyre gyarapodó tengeralattjáró-állomány lehetővé tette a BdU-nak (Befehlshaber der Unterseeboote), hogy alkalmazza a Dönitz admirális által kitalált falkataktikát. Erre a német parancsnokságot a szövetséges kísérőhajók számának növekedése is késztette. A falka megosztotta a kísérőhajókat és egyszerre több oldalról támadta a konvojokat. A briteket domíniuma, Kanada, valamint az Egyesült Államok is erőteljesen segítette, bár ez utóbbi még semleges ország volt. Az USA 50 darab első világháborús rom-

20. ábra. Egy bevetésből visszatért egység kikötés közben, a legénység üdvözlő állásban áll a fedélzeten. A periszkópon öt darab elsüllyesztett hajót jelképező kis zászló lobog

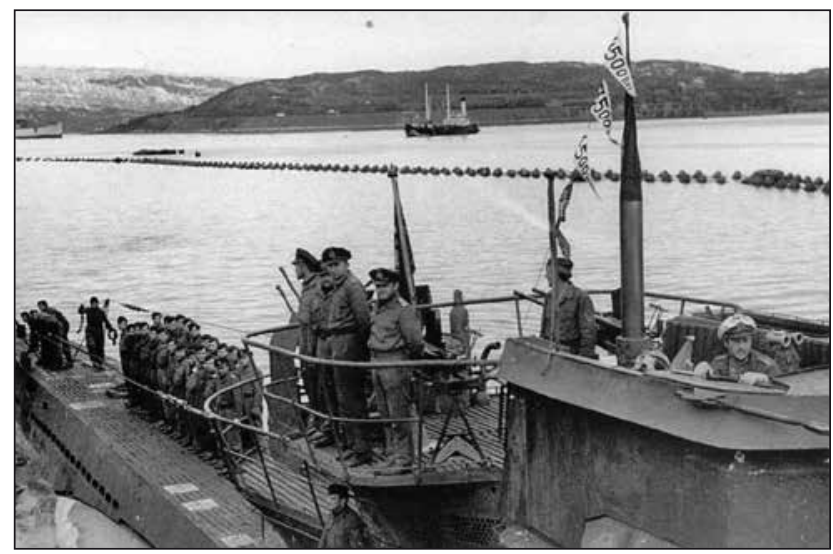

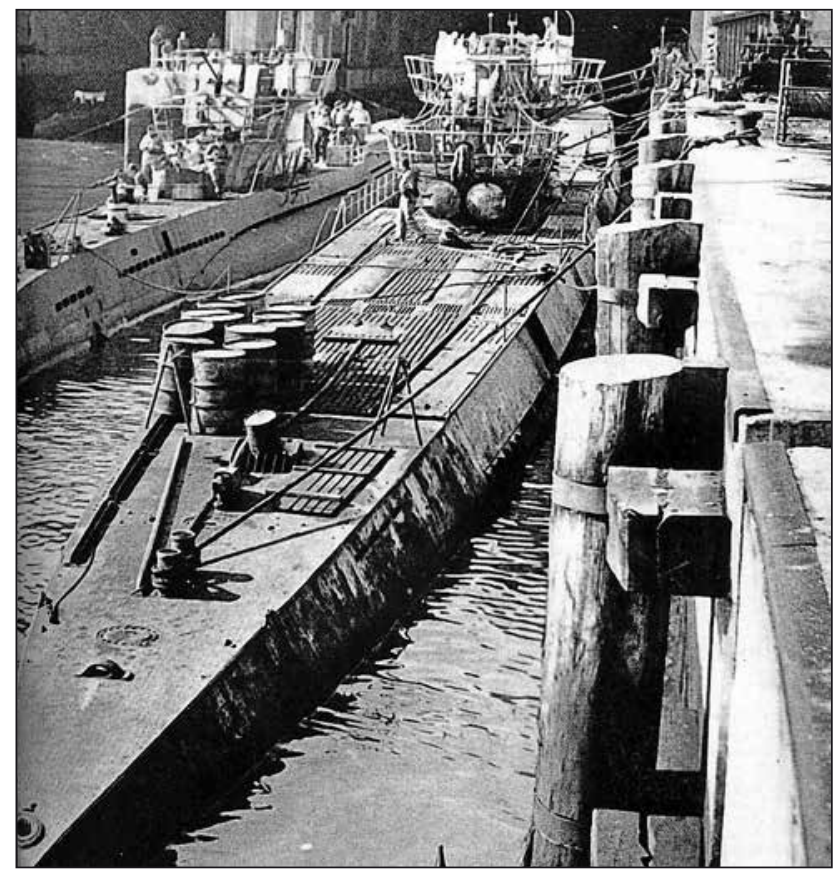

21. ábra. Két VII. osztályú tengeralattjáró a kikötőben. Mögöttük légitámadás ellen védő bunker. A kép feltehetően Franciaországiban készült

bolót adott át, majd Izlandig saját hadihajó-kíséretet is biztosított a konvojok számára. A VII. osztály, és az első, valamint a második generációs U-boot-ok gyengéje a felderítőeszközök hiánya volt. Mivel a hajók nem voltak rádiólokátorral felszerelve, így sem a vízfelszíni, sem a légi célokat nem tudták nagyobb távolságban felderíteni. (Az amerikai tengeralattjárók rendelkeztek rádiólokátorral - Szerk.) A Luftwaffe gyakorlatilag minimális támogatást adott Focke Wulf 200 Condor távolfelderítő gépeivel, így a búvárnaszádok, alacsony parancsnoki tornyainak távcsővel felszerelt őrszemei voltak a legnagyobb hatótávolságú felderítőeszközeik. A hajókon víz alatt passzív hanglokátorral keresték a hajók, konvojok zaját. Ezzel általában előbb tudták a felszíni egységek irányát meghatározni, és a zaj felé induló búvárhajók vették észre a hajók kéményeiből gomolygó füstöt.

1943-tól kezdve az Atlanti-óceán két partjáról és Izlandról, valamint a kísérő hordozókról felszálló szövetséges

* ORCID: 0000-0001-5563-3313

** Mérnök, a Haditechnikai Intézet ny. tanácsosa, a Haditechnika folyóirat korábbi szerkesztője, ORCID: 000-0002-2008-7997 


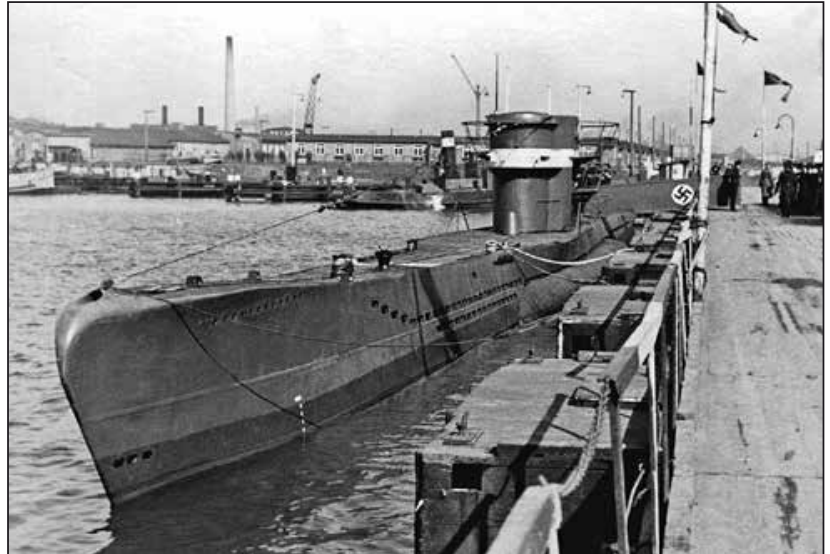

22. ábra. Indulás előtt álló hajóegység egy német kikötöben. A legénység még a parton áll. A tornyon látható fehér jelzés alapján a felvétel még a háború előtt készülhetett

repülőgépek kezdték pásztázni az óceánt, ezzel a német tengeralattjárók vízfelszíni hajózására komoly veszélyt jelentettek. A repülőgépekkel támogatott konvojok támadása nehéz volt, mivel a felszíni megközelítés, valamint a konvoj követése, a légi támadás veszélye miatt nappal szinte lehetetlenné vált. A VII. osztály hajói merülésben elektromotorokkal - a lassú konvojok kivételével - nem tudták már követni a felderített hajócsoportokat. 1943 végére az angolszász tengeralattjáró-vadász repülők, a levegőből ellenőrzés alatt tartották szinte az összes hajózási útvonalat az Atlanti-óceánon. Ezért a német parancsokság, a hollandok találmányát modernizálva megkezdte a légperiszkóp (schnorkel) felszerelését a VII. osztály naszádjaira - minőségi fölényként ellensúlyozva a szövetségesek mennyiségi fölényét. Ez az eszköz lehetővé tette, hogy a tengeralattjáró periszkópmélységben haladva használhassa dízelmotorjait. A légperiszkóp, azonban hangos volt, ezért a passzív hangérzékelést rontotta, valamint a vizuális felderítést is nehezítette. A falka taktikára további komoly csapást jelentett az ENIGMA rejtjelző berendezés feltörése, mivel a német parancsnokság rádióüzenetekkel irányította a tengeralattjárókat a felderített konvojok felé, valamint az U-boot-ok szintén rádión jelezték eredményeiket, fegyverzetük és üzemanyaguk mennyiségét, valamint a felderítési adatokat. A német tengeralattjáró-parancsokság a világháború végéig nem tudta meg, hogy rádióforgalmazásukat megfejtették. A britek, a konvojokat elirányították a farkasfalkák útjából, és gyors rombolókból és fregattokból álló vadászcsoportokat állítottak össze, amelyek feladata a

23. ábra. Egy javítást végző mühelyhajó mellé kikötött U VII-es típus, valószínúleg egy norvég kikötőben

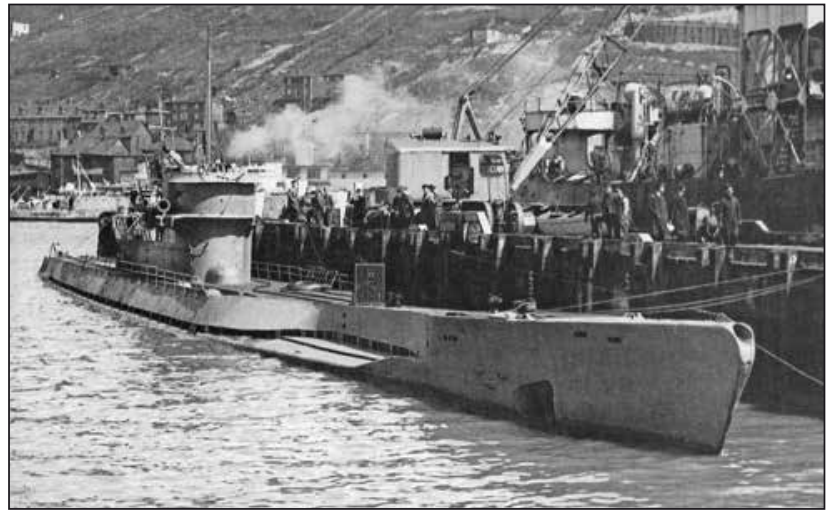

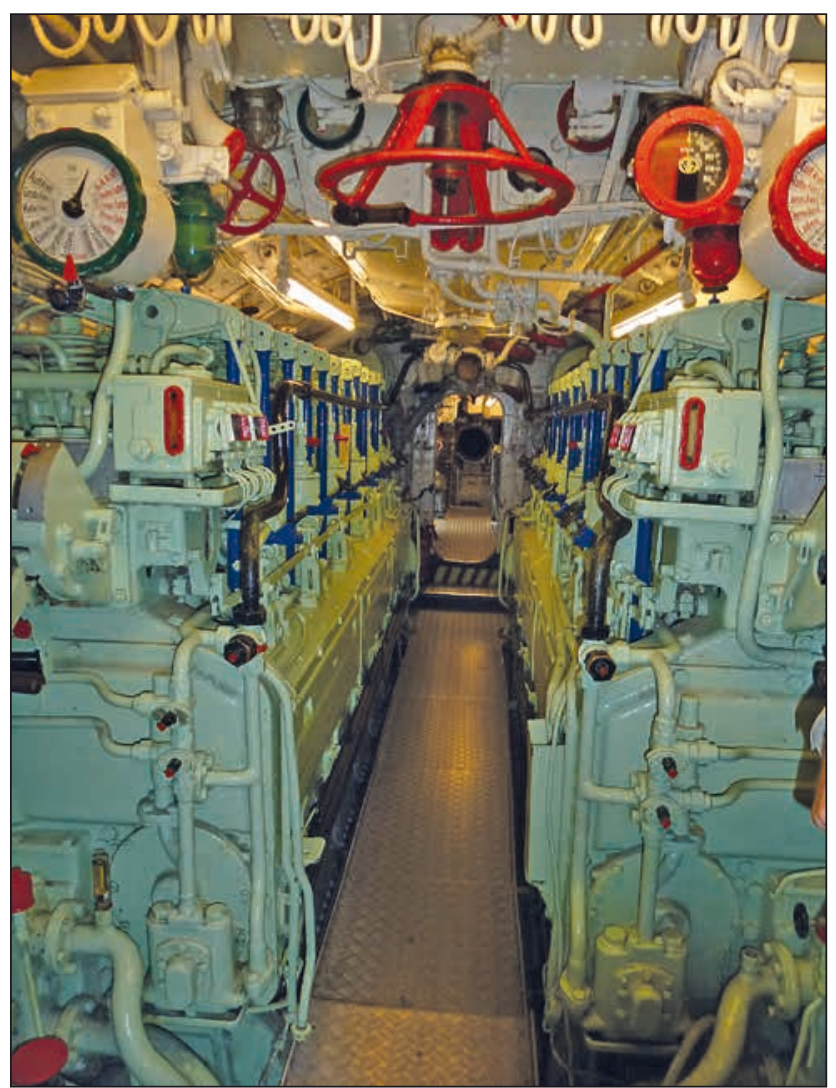

24. ábra. Az U 995-ös gépterme a két dízelmotorral.

A dízelmotorjai 665 kW (kb. 905 LE-s) teljesítményt adtak le

25. ábra. Az U 995-ös parancsnoki központja

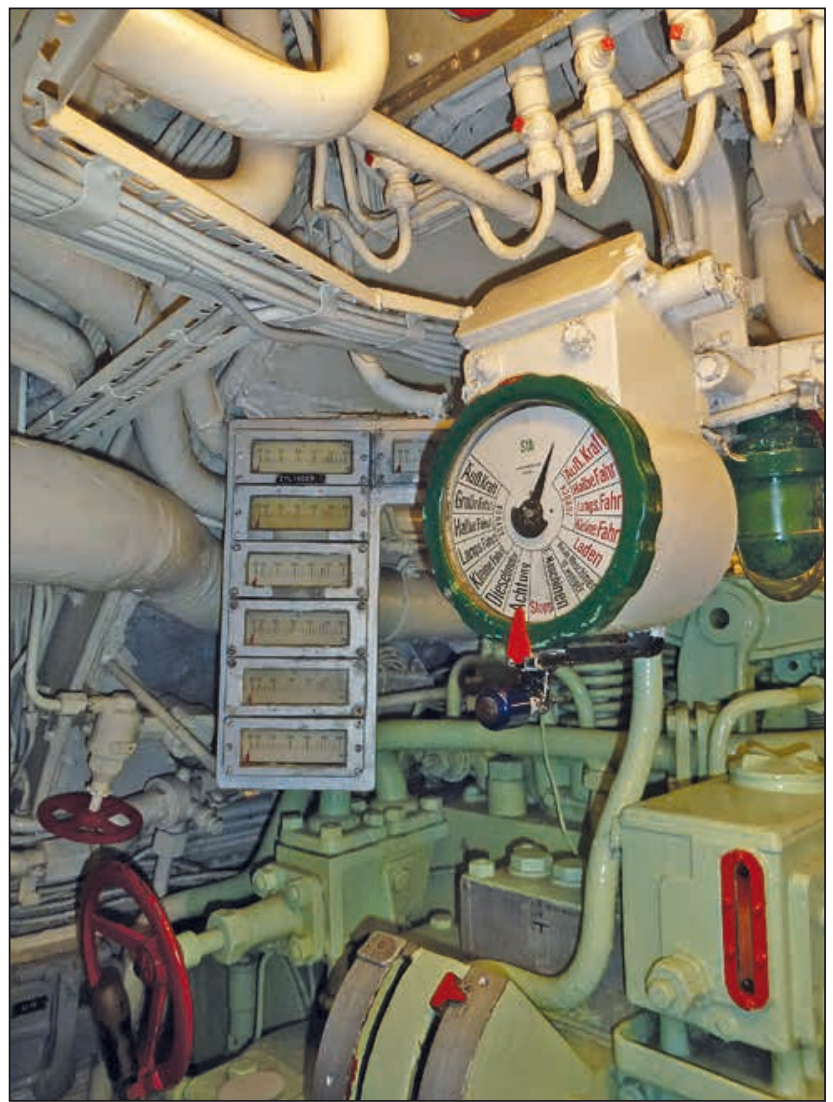




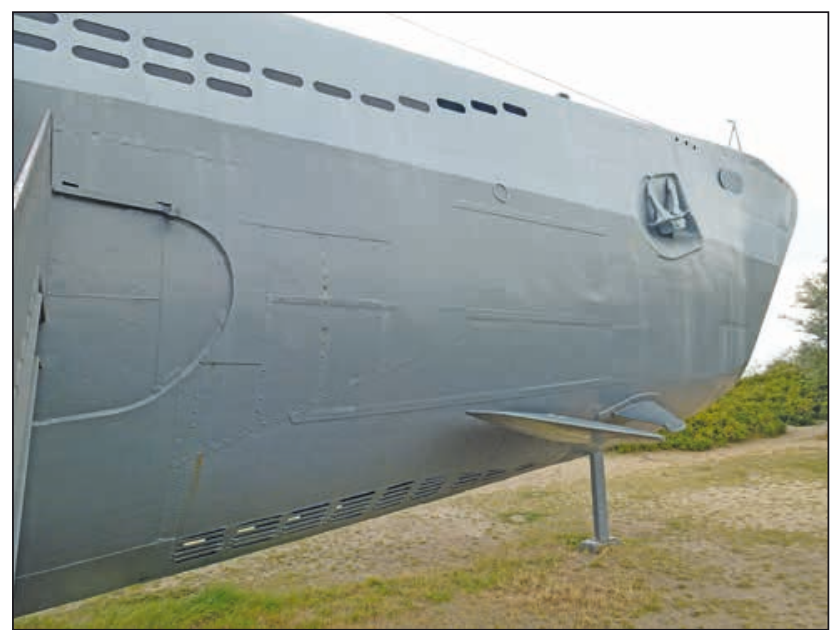

26. ábra. A VII. osztályú tengeralattjárók orr-része

felderített búvárhajók elleni küzdelem volt. A passzív, védelmi jellegű konvojkíséret mellett tehát, támadó feladatú tengeralattjáró vadászcsoportok csaptak le a falkákra. A németek a szövetségesek korszerü lokátortechnikájára és a rádióbemérésére gyanakodtak, miután tengeralattjáróik elleni támadások megsokasodtak. A második generációs tengeralattjáróikat, köztük a VII. osztályt a légperiszkóp mellett radar-besugárzás jelzőkkel látták el. Ezek a készülékek azonban csak néhány hullámhossztartományt tudtak lefedni, a szövetségesek pedig többfajta, más-más hullámhossz tartományon működő lokátorberendezéseket használtak hajóikon, majd kellően miniatürizálva repülőgépeiken is. A felderítő-berendezéseken kívül nagy problémát jelentett, hogy a VII. és IX. osztályú flotta-tengeralattjárók vízfelszíni sebessége csak az elavultabb régebbi korvettek és átalakított tengeralattjáró-elhárítókét múlták felül, a fregattok és rombolók azonban jóval gyorsabbak voltak. A tengeralattjárók ezért felszínen sem támadni, sem menekülni nem tudtak. A sebességen kívül a lokátorok a búvárnaszádok felszíni helyét is megmutatták, sőt a hábo- rú végén már a hajólövegeket is vezérelték. A VII. osztályú naszádok víz alatti sebessége még ennél is problémásabb volt, lemerülve a 7-8,5 csomós (13-16 km/h) csúcssebességgel fél/egy órát tudtak haladni, amely támadáshoz elegendő volt, de az ellenség követésére, vagy elszakadásra 1943 után már kevésnek bizonyult. A búvárnaszádokkal egyetlen lehetőség a mélységet változtatva, csöndben, elektromotorok kímélésével, a különböző vízrétegek közti manőverezés, valamint a minél mélyebbre merülés volt, a mélység ugyanis rontotta a felszíni hajók hanglokátorainak (szonárok) észlelőképességét. A nagyobb vízmélység ugyanakkor sérülés esetén csökkentette a tengeralattjárónak és a legénység tagjainak túlélőképességét.

A sebességi problémákra a németek találtak megoldást, és a VII. és IX. osztály helyett áramvonalas, a vízfelszínivel azonos, vagy nagyobb víz alatti sebességú új tengeralattjárókat terveztek XXI. és XIII. osztály néven. Ezeknek a hajóknak elődeikénél lényegesen nagyobb volt az akkumulátorkapacitásuk. Emellett kísérleteket folytattak a Waltermotoros meghajtással is. A Walter-motor meghajtását kazán helyett gázolaj-befecskendezéses égőtérrel táplált gőzturbina biztosította, ahol a munkaközeg a vízgőz mellett gázt is tartalmazott. Az 1942-ben indult program azonban számos műszaki problémával küszködött, végül csak három darab kísérleti, és - XVIII. osztály néven - két flottatengeralattjáró, az U 796-os és az U 797-es készült el, de 1944-ben, bombatámadás miatt mindkettő még a hajógyárban megrongálódott. A XXI. osztály építése 1944 nyarán kezdődött, és a háború végéig 118 darab készült. A harmadik generációs tengeralattjárók víz alatti sebessége elérte a 17,2 csomót $(31,85 \mathrm{~km} / \mathrm{h})$. Az új hajókon a torpedók töltése teljesen gépesített volt, 10 percen belül minden orrtorpedót újratölthettek. A hajók kezelése az alkalmazott technikai újdonságok miatt hosszabb kiképzést kívánt, ezért csak az U 2511-es és az U 3008-as állt hadrendbe, azok két őrjáratot teljesítettek, de találatot nem értek el. (Az őrjáratok inkább az új tengeralattjárók éles próbái voltak.) Az elhúzódó fejlesztések miatt, a német tengeralattjáró-parancsokság 1944-ben és 1945-ben kénytelen volt a régebbi VII. és IX. osztályú hajókat légpe-

\section{7. ábra. Az U 995-ös a Laboe-i tengeralattjárós emlékhelyen. Ez az egyetlen megmaradt VII. osztályú tengeralattjáró}

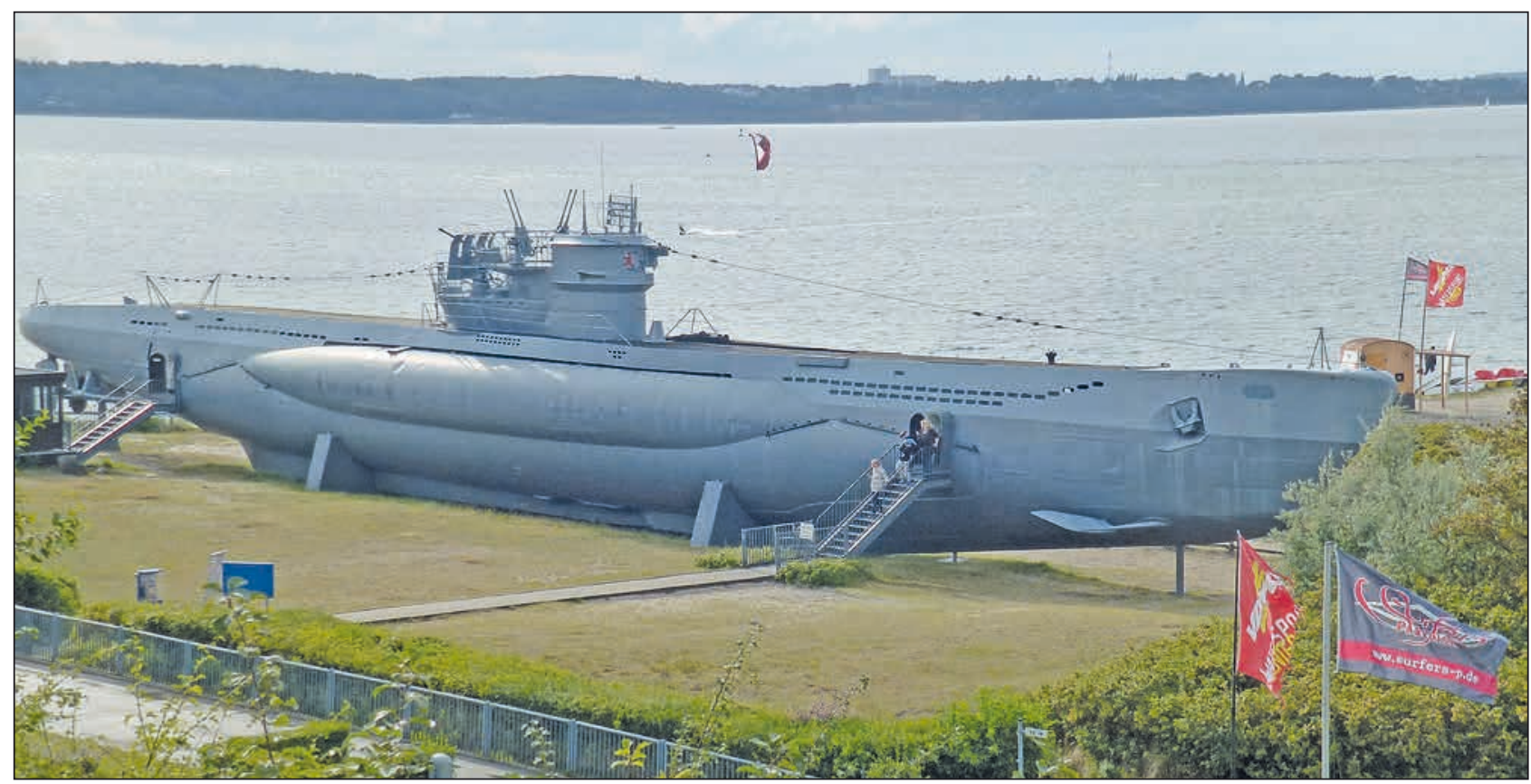


2. táblázat. Az elsüllyesztett hajótér, a bevetett német tengeralattjárók és veszteségeik aránya számokban

\begin{tabular}{|c|c|c|c|}
\hline Év & Elsüllyesztett hajótér (brt.) & Tengeralattjárók száma (db) & Tengeralattjárók vesztesége (db) \\
\hline 1939 & 0,6 millió & $52-57$ & 26 \\
\hline 1940 & 2,3 millió & $54-75$ & 38 \\
\hline 1941 & 2,2 millió & $82-253$ & 88 \\
\hline 1942 & 5,8 millió & $266-386$ & 245 \\
\hline 1943 & 2,3 millió & $403-436$ & 264 \\
\hline 1944 & 0,6 millió & $458-485$ & 399 \\
\hline 1945 & 0,2 millió & $403-407$ & \\
\hline
\end{tabular}

riszkóppal ellátva, lokátor-besugárzás jelzőkkel, valamint újonnan kifejlesztett torpedókkal harcba küldeni a szövetséges konvojok ellen. Az új G7e (T 3-as) és (T 4-es) elektromos torpedók kiküszöbölték a régebbi G7e (T 2-es) hiányosságait, mert megbízhatóbb mágneses közelségi gyújtójuk volt. A G7 Zaunkönig torpedó irányítórendszere a hajócsavar zajára vezette rá a torpedót. Német taktika szerint elsősorban a kísérőhajók kilövésére, illetve fartorpedóként önvédelmi fegyvernek fejlesztették ki.

A T XI (Zaunkönig II) viszont egy elliptikus körpályára lanszírozható torpedó volt, amely addig körözött, ameddig célt talált, vagy hajtóanyaga elfogyott. Utóbbit a konvojoktól viszonylag távolról indították, remélve, hogy a sok hajó közül az egyiket eltalálja. Az új torpedókat 1943 szeptembertől 1945 áprilisig vetették be. Rombolókat, fregattokat és egyéb kísérőhajókat is elsülyesztettek. A szövetséges tengeralattjáró-elhárító egységek hamarosan vontatott zajkeltők alkalmazásával csökkentették az akusztikus torpedók hatékonyságát. A VII. osztályú hajók továbbra is harcoltak, de a gyenge felderítési képességek, a lassú sebesség és a kis merülési idő miatt egyre nagyobb hátrányba kerültek. A hajók parancsnokai óvatossá váltak, a nappali

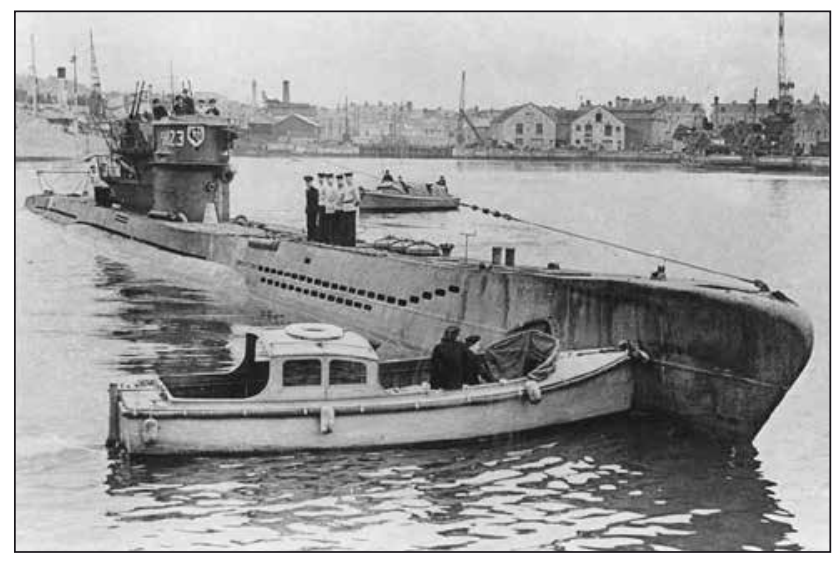

29. ábra. Egy U VII-es osztályú tengeralattjáró, gyári javítás után elhagyja a szárazdokkot

órákat általában merülésben töltötték. Éjszaka légperiszkóppal igyekeztek a hadműveleti területekre, amely az Atlanti-óceánról áttevődött a brit szigetek körüli vizekre.

28. ábra. Egy korszerübb német második világháborús tengeralattjáró. A XXI. osztályú WILHELM BAUER ex. U 2540-es, technikai múzeumként Bremerhaven kikötőjében látogatható. A XXI. osztályú electro-boot-ok jóval nagyobb víz alatti sebességükkel, gépi vezérlésű torpedóvető csövekkel a késöbbi amerikai és szovjet tengeralattjárók mintájaként is szolgáltak

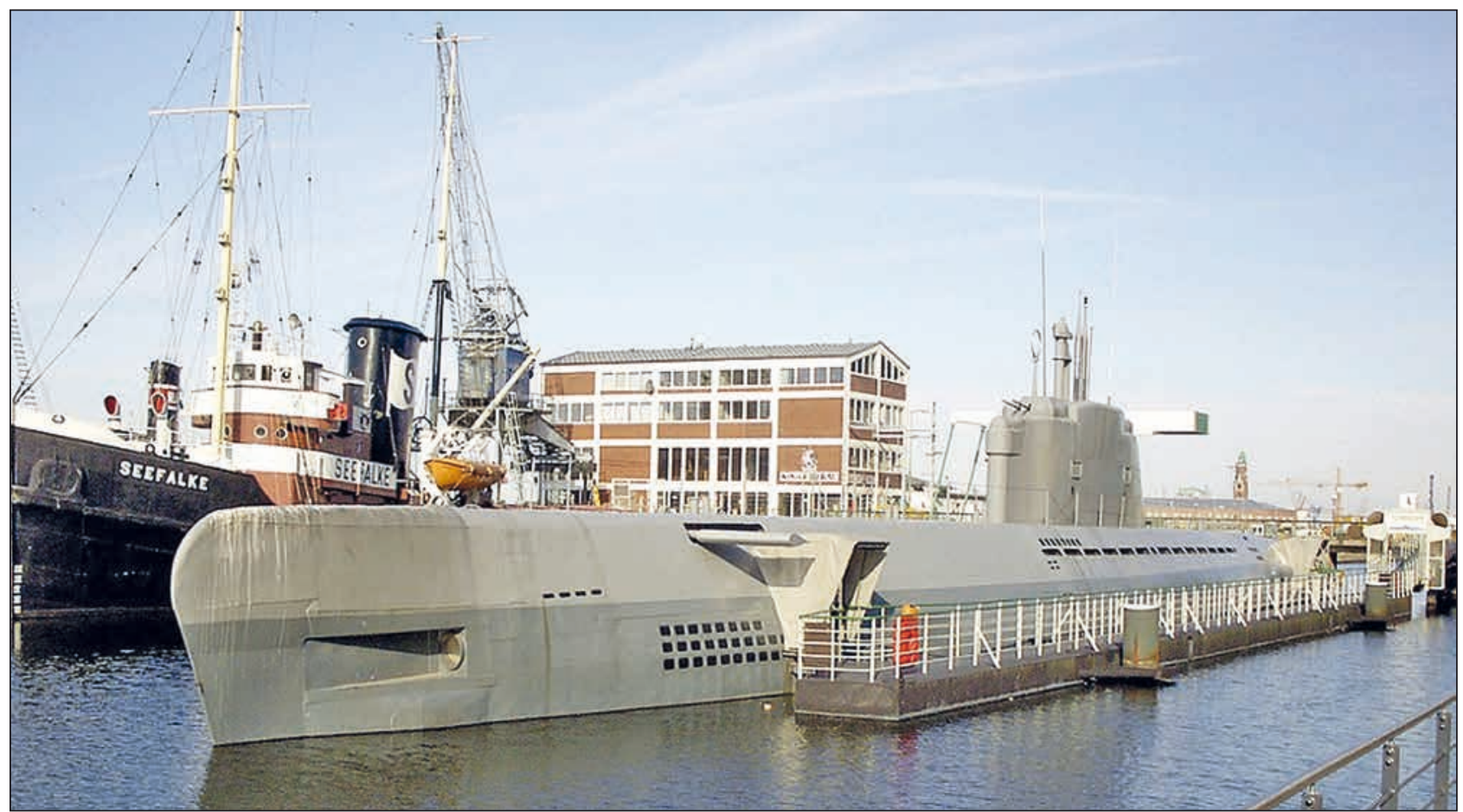


3. táblázat. Az U VII. osztály összesített gyártási adatai:*

\begin{tabular}{|c|c|c|c|c|}
\hline \multirow{2}{*}{ Változat } & \multirow{2}{*}{ Tervezett darabszám } & \multicolumn{3}{|c|}{ Elkészítve } \\
\cline { 3 - 5 } & & Építés megkezdve & Vízre bocsátva & Építés befejezve \\
\hline $\mathrm{A}$ & $10 \mathrm{db}$ & $10 \mathrm{db}$ & $10 \mathrm{db}$ & $10 \mathrm{db}$ \\
\hline $\mathrm{B}$ & $24 \mathrm{db}$ & $24 \mathrm{db}$ & $24 \mathrm{db}$ & $24 \mathrm{db}$ \\
\hline $\mathrm{C}$ & $643 \mathrm{db}$ & $593 \mathrm{db}$ & $58 \mathrm{db}$ & $577 \mathrm{db}$ \\
\hline $\mathrm{C} 41$ & $323 \mathrm{db}$ & $239 \mathrm{db}$ & $91 \mathrm{db}$ & $0 \mathrm{db}$ \\
\hline $\mathrm{C} 42$ & $442 \mathrm{db}$ & $165 \mathrm{db}$ & $6 \mathrm{db}$ & $6 \mathrm{db}$ \\
\hline $\mathrm{D}$ & $6 \mathrm{db}$ & $6 \mathrm{db}$ & $4 \mathrm{db}$ & $4 \mathrm{db}$ \\
\hline F & $4 \mathrm{db}$ & $4 \mathrm{db}$ & $\mathbf{7 1 7} \mathrm{db}$ & $\mathbf{7 0 9} \mathrm{db}$ \\
\hline
\end{tabular}

*A kimutatás az összes típust tartalmazza, amely a Kriegsmarine főparancsnokságán lajstromba került. A 411 darabos eltérést a tervezett és a megkezdett építés között az acél- és kapacitáshiány, illetve a típus elavulásának oka indokolta. A 324 darabos eltérést az építést megkezdett és a vízre bocsátott egységek között a háborús bombakárok, a gyárak sérülései és egyes fő darabok hiánya okozta. A sérült hajótesteket lebontották. A 8 darabos hiányt a befejezett hajóknál már a háború végén beállt termeléskiesés és alkatrészhiány okozza.

A német búvárnaszádok közül, 5102 őrjárat során 862 vett részt bevetésen a második világháborúban. Ezek döntő többségén a VII. osztályú tengeralattjárókkal indultak harcba a német tengerészek. A harcok során $218 \mathrm{db}$ szövetséges hadihajót süllyesztettek el az U-boot-ok, amelyek között 13 nagyobb volt, mint 4000 brt. (bruttó regisztertonna) vízkiszorítású. A nehéz hajóegységek közül a HMS NELSON, HMS ROYAL OAK, HMS BARHAM, HMS MALAYA, HMS IRON DUKE csatahajókat, a HMS THANE, HMS NABOB, HMS ARK ROYAL, HMS EAGLE, HMS COURAGEOUS, HMS AVANGER, HMS AUDACITY, USS BLOCK ISLAND repülőgép-hordozókat süllyesztették el, vagy rongálták meg német tengeralattjárók.

A kereskedelmi egységek közül 3305 hajó torpedótámadás, vagy tengeralattjáró által telepített aknákon sérült meg, süllyedt el. Ezek közül 1664 brit, 549 amerikai, 314 norvég, 137 holland és 124 görög hajó, a többi más szövetséges állam, vagy semleges ország hajója volt. Az elsüllyesztett hajók közül 21 darab vízkiszorítása haladta meg a 15000 brt.-t, a legnagyobb egység a VII-es osztályú U 32 által megtorpedózott EMPRESS OF BRITTAIN volt, 42348 brt.-s vízkiszorítással.

A világháború végére a VII. osztály 709 egységéből 71 darab maradt, és ezekből 1945 májusában 45-tel hajtottak végre önelsüllyesztést. A maradék egységeket szétbontották. Napjainkra egyetlen VII. osztályú tengeralattjáró, az U 995-ös maradt meg. A 45 fős legénységű tengeralattjáró KAURA néven, norvég zászló alatt mint iskolahajó szolgált 1952-ig, és sok NATO-hadgyakorlaton vett részt. 1965ben úgy döntött a norvég haditengerészet, hogy a megbékélés jeleként, átadják Nyugat-Németországnak. 1965. október 14-én vontatóhajóval került át Kielbe, ahol 750000 márkába került a tengeralattjáró partra állítása, valamint helyrehozatala. Először Münchenben akarta kiállítani a Deutsches Museum, de a szállítási nehézségek, és a jelentős költségek miatt erről lemondtak. Végül a Balti-tenger partján fekvő Leboe városába került. Az U 995-ös, a nagyközönség számára végül 1972. március 13-án vált látogathatóvá. A végleges kiállítás installációja - a búvárnaszád melletti német haditengerészeti emlékművel együtt 900000 márkába került. A hajó folyamatos karbantartása évente jelentős költséget jelent, de eddig már több mint 500000 ember látogatta meg az U 995 öt.

A tengeralattjáró elit fegyvernemnek számított, és a háború elején a legénység önkéntesekből állt. 1943-tól már a haditengerészet más fegyvernemeiből, az egészségügyileg alkalmas katonákat is átképezték tengeralattjárósnak. Ami a kereskedelmi hajók felszólítás nélküli megtorpedózásáról szóló parancsokat illeti, Chester W. Nimitz tengernagy, az Amerikai Egyesült Államok Haditengerészete tengeralattjáróinak parancsnoka, Karl Dönitz tengernagy háborús búnös perének tárgyalására átrepült az Államokból hogy Dönitz mellett tanúskodjon. Kijelentette, hogy hasonló parancsokat adott az amerikai tengeralattjáróknak a japán hajókkal szembeni tevékenykedésre. Tanúvallomása mentette meg Dönitzet a kötél általi haláltól.

Az U 995-ös és a Leboe-ban lévő haditengerészeti emlékmü 39000 tengeralattjárósnak állít emléket. Közülük 32000 tengerésznek, és az általuk megsemmisített kereskedelmi és hadihajókon szolgálatot teljesítő embereknek is a Föld tengerei és óceánjai váltak végső nyughelyükké. A tengeralattjárósok közül a legtöbb tengerész VII. osztályú hajón vesztette életét.

\section{IRODALOMJEGYZÉK}

Bernard Edwards: Dönitz Farkasfalkái: Az Atlanti-csata 1939-1945. Bp.: LAP-ICS Könyvkiadó,1998, Aquila könyvek sorozat;

Sárhidai Gyula: Tengerek szürke farkasai. Bp.: Maecenas könyvkiadó, 1989.;

Paul Herbert Freyer: Halál a tengereken. Bp.: Zrínyi Katonai Kiadó, 1979.;

Lothar Günther Bucheim: A hajó. Bp.: Magvető Kiadó, 1982.;

Geoffrey Brooks: Hirschfeld - Egy német tengeralattjáróaltiszt története, 1940-1946. Debrecen, Hajja \& Fiai Könyvkiadó, 2003.;

Norman Franks, Eric Zimmerman: U-Bootok harca a repülőgépekkel. Debrecen, Hajja \& Fiai Könyvkiadó, 1999.;

Robert C. Stern: Type VII U-boats. London: Arms and Armour Press, 1997 .

The U-boat Wars 1939-1945 (Kriegsmarine) and 1914-1918 (Kaiserliche Marine) and Allied Warships of WWII. http://www.uboat.net/ [2018.04.18.];

Eberhard Rössler: Die Torpedos der deutchen U-Boote, Verlag E.S. Mitter\&Sohm GmbH Hamburg, 2005. 